\title{
Corrigendum: Detecting and Predicting Emerging Disease in Poultry With the Implementation of New Technologies and Big Data: A Focus on Avian Influenza Virus
}

\author{
Jake Astill ${ }^{1}$, Rozita A. Dara ${ }^{2}$, Evan D. G. Fraser ${ }^{3}$ and Shayan Sharif ${ }^{1 *}$ \\ ${ }^{1}$ Department of Pathobiology, University of Guelph, Guelph, ON, Canada, ${ }^{2}$ School of Computer Science, University of \\ Guelph, Guelph, ON, Canada, ${ }^{3}$ Arrell Food Institute and Department of Geography, Environment and Geomatics, University \\ of Guelph, Guelph, ON, Canada
}

Keywords: influenza virus, poultry, rapid diagnosis, big data, biosensor, infectious disease

\section{OPEN ACCESS}

Approved by:

Frontiers in Veterinary Science, Frontiers Media SA, Switzerland

*Correspondence:

Shayan Sharit

shayan@uoguelph.ca

Specialty section:

This article was submitted to Veterinary Infectious Diseases, a section of the journal Frontiers in Veterinary Science

Received: 14 December 2018 Accepted: 17 December 2018

Published: 22 January 2019

Citation:

Astill J, Dara RA, Fraser EDG and

Sharif S (2019) Corrigendum: Detecting and Predicting Emerging

Disease in Poultry With the

Implementation of New Technologies and Big Data: A Focus on Avian Influenza Virus. Front. Vet. Sci. 5:337. doi: 10.3389/fvets.2018.00337

\section{A Corrigendum on}

Detecting and Predicting Emerging Disease in Poultry With the Implementation of New Technologies and Big Data: A Focus on Avian Influenza Virus by Astill, J., Dara, R. A., Fraser, E. D. G., and Sharif, S. (2018). Front. Vet. Sci. 5:263. doi: $10.3389 /$ fvets. 2018.00263

Two author names were incorrectly provided as "Rozita Dara and Evan Fraser." The names should be "Rozita A. Dara and Evan D. G. Fraser." The order of the authors has also been corrected, as this was mistakenly changed during the manuscript revisions. Rozita A. Dara should appear as the second author and Evan D. G. Fraser should appear as the third author.

Additionally, there was an error in affiliation 3. Instead of the "Department of Geography, Environment and Geomatics, University of Guelph, Guelph, ON, Canada," it should be the "Arrell Food Institute and Department of Geography, Environment and Geomatics, University of Guelph, Guelph, ON, Canada."

Lastly, there was an error in the keywords listed. A correction has been made to the Keywords.

"Keywords: influenza virus, poultry, rapid diagnosis, big data, biosensor, infectious disease"

The authors apologize for these errors and state that they do not change the scientific conclusions of the article in any way. The original article has been updated.

Copyright $\odot 2019$ Astill, Dara, Fraser and Sharif. This is an open-access article distributed under the terms of the Creative Commons Attribution License (CC BY). The use, distribution or reproduction in other forums is permitted, provided the original author(s) and the copyright owner(s) are credited and that the original publication in this journal is cited, in accordance with accepted academic practice. No use, distribution or reproduction is permitted which does not comply with these terms. 